\title{
Charting a new course for Deptford Town Hall
}

By Paul Hendrich (Goldsmiths, University of London)

Goldsmiths, one of the colleges in the University of London, is the current owner of Deptford's former Town Hall, an ornately sculpted building on a maritime theme. Controversially, the figures celebrated on the front of this building have close associations with the British slave trade. The paper attempts a new historicisation of Goldsmiths in relation to Deptford Town Hall, racism and resistance to racism. It further explores anthropological theory and methods in order to ascertain the institutional responsibilities of Goldsmiths to adequately address this controversial artefact. Finally I briefly examine how theory can inform action in the development of a local campaign.

\section{Introduction: Deptford Town Hall}

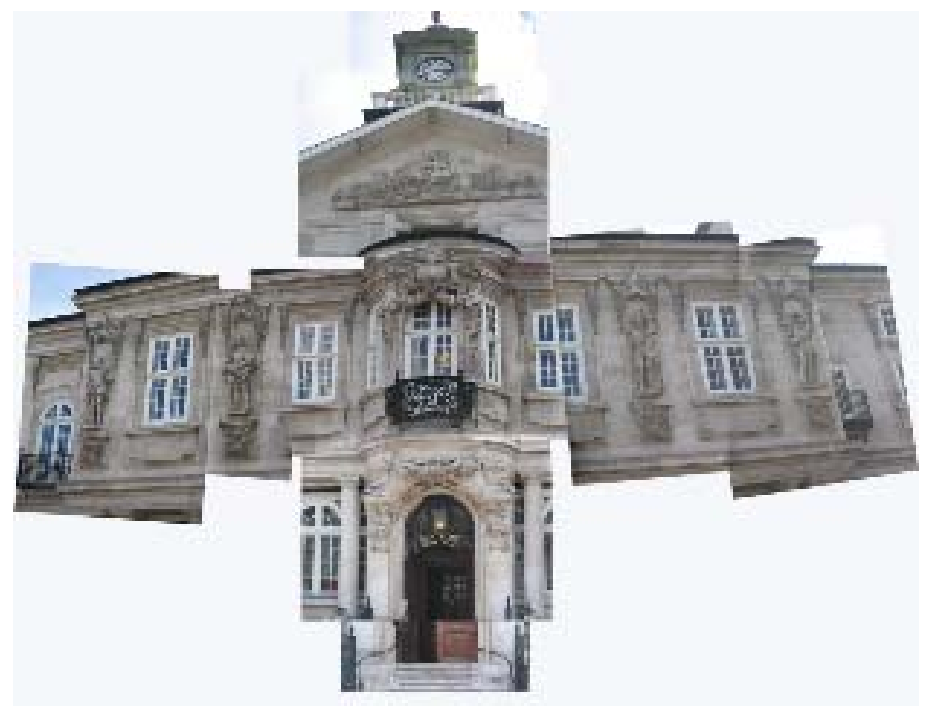

In 1998 Goldsmiths College took receipt of Deptford Town Hall, ${ }^{*}$ a compact ornately sculpted building on a maritime theme that stands in contrast to the more functional architecture of New Cross Road, Deptford, South London. The Goldsmiths College site had its beginning as a naval college. The Goldsmiths Company later occupied the site, and the school subsequently became part of the University of London in 1905, the same year as Deptford Town Hall's completion (Firth 1991). Like twins separated at birth Goldsmiths and Deptford Town Hall have been prominent features of New Cross for just over a century, and when Joan Ruddock MP handed the Town Hall to

\footnotetext{
${ }^{*}$ More pictures can be seen at www.anthropologymatters.com/journal/2008-1/hendrich 2008 charting.html
} 
the College, the two were no longer divided but became part of the same institution. However, in becoming one institution a new set of questions arose.

Atop the Town Hall is a golden ship. This is not a surprising symbol for Deptford considering its 400-year history at the centre of British overseas trade. If we examine the other major ornaments on the front of the building, four historical figures carved in Portland stone, we are left like Les Back asking: 'What kind of ship is it? A warship? A trader? A slave ship?' (Back 2003:3). We could see allusions to any or all of these types of ships as the four figures in question are Sir Francis Drake, Robert Blake, Lord Horatio Nelson and a composite figure that represents a typical admiral of the Edwardian period when the building was completed. It is well documented that Drake was involved in capturing and selling slaves. Blake and Nelson were less directly implicated but have had a hand in the British slave trade by association (Anim-Addo 1995).

The College's ownership of Deptford Town Hall has created a further question about the appropriateness of Goldsmiths being in possession of these statues of infamous characters. There are a number of people for whom the irony of this situation is clear, since Goldsmiths prides itself in being 'the UK's leading creative university' (see e.g. Goldsmiths' website). The College has a reputation for turning out 'cutting edge' individuals. In the social sciences there are a number of academics who have made race and racism a major part of their writing. This includes Les Back and Paul Gilroy, 'a major contributor to political, historical and sociological debates on racism, nationalism and multiculture' (URL 1). Yet nothing has been done to address this contradiction. That could be in part because nobody has an idea of what could be done.

\section{Methodological considerations}

At the heart of this article is the reflexive twist of my examination of the institution to which I belong, Goldsmiths College, and the attitudes of those within and around the College, including myself. The initial challenge came in a seminar discussion when a comment was made to the effect of 'nothing can be changed at Goldsmiths'. My classmate went on to characterise the College as a monolithic institution that we had no power to change. I felt that this display of apathy was shocking, especially as it was a community worker who expressed it. The fact that several of my cohorts agreed with this apathetic position added to my discomfort. As a result I began organising around the issues relating to Deptford Town Hall in part to explore if this characterisation was accurate.

One of Goldsmiths College's unique combinations is the course that I was taking, an academic and professional course that brings together anthropology with community and youth work. The common attribute of both professions is the self-reflexivity involved in the process of working. However, unlike anthropologists, community and youth workers are expected to get involved, take political positions and actively attempt to enact change. This does not sit comfortably with some within anthropology. But other anthropologists (e.g. Berreman 1968, Kirsch 2002, ScheperHughes 1995) have advocated for and routinely taken 'non-neutral' positions in relation to their research subjects and their interests.

When I was considering how I might synthesise these different professional positions, I looked for a common methodological approach that could bring together theory and 
action in a framework sympathetic to both disciplines. The work of Paulo Freire (1972) and subsequently David Kolb's learning cycle (or spiral) (Thompson 2000) asks that the organiser should constantly reflect on the action they take. 'Activity consists of action and reflection: it is praxis; it is transformation of the world. And as praxis, it requires theory to illuminate it. Men's [and women's] activity is theory and practice; it is reflection and action' (Freire 1972:96).

I have chosen to use an action research framework to address participation, selfreflection, theory and action. Action research encourages practical outcomes and personal growth. As a methodological approach action research is extremely flexible. Action research is not, however, a research technique. It is instead a focus on the 'relationships between social and educational theory and practice' (Kemmis and Wilkinson 1998:34). Action research allows for participants to make use of a variety of techniques in order to generate data. To this end I have mainly employed ethnography, an 'immersion of the researcher in the setting' (Robson 2002:89). As a student at Goldsmiths I was immersed in this setting. I interviewed and talked with people in and around Goldsmiths and Deptford about their relationship with Deptford Town Hall. As a researcher and student I interviewed an evenly distributed crosssection of academic and non-academic staff, local residents, and students, although I am aware that this particular account privileges my academic informants.

In the course of this article I attempt to create a different historicisation of events in relation to Goldsmiths and Deptford Town Hall. The campaign, linked as it is to race and anti-racism, is a political act and cannot be 'divorced from other political processes' (Gilroy 1992:51). The generation of this alternate history is one of these political processes. Joan Scott recognises the importance of understanding that the traditional view of history is not value-free in respect to politics:

History is not purely referential but is rather constructed by historians. Written history both reflects and creates relations of power. Its standards of inclusion and exclusion, measures of importance, and rules of evaluation are not objective criteria but politically produced conventions ... today's contests are about how history will be constituted for the present. 'History is past politics and politics present history' [the American Historical Association's motto]. (Scott 1989:681)

\section{Horrible histories}

I am not Deptford born. I have had an association with Goldsmiths and Deptford for only three years. I knew nothing about the area when I started to involve myself in this campaign short of how to get there by bike or bus. I had not really noticed the ship until it was pointed out to me during a chat in the pub. 'The ship on top of Deptford Town Hall,' I was told, 'is a slave ship.' I decided to investigate.

Deptford Town Hall is 'a memorable ensemble' in the Baroque style (English Heritage 2006). The souvenir brochure of the Town Hall's 1905 opening boasts that 'it will hardly be denied that in the whole of South London no more artistic and tasteful piece of architecture could be found' (Borough of Deptford 1905:16). The façade has an overhanging first floor supported by Doric columns. In the centre, above a cave-like entrance, is an oriel window in the first floor supported by atlantes, carved mermen or tritons. The four intricately carved statues of famous naval figures mentioned above are set between the windows of the first floor. Each is complete with details of dress, and a small wreath set below each shows variously their nautical 
tools, the accoutrements of faith and the spoils of war, piracy and trade. Sitting upon the main structure is an imposing attic pediment complete with a naval battle carved into it. A large four-sided clock turret further tops this. Sailing above the whole of this marvellous spectacle is a golden galleon serving as a weathervane. The ship on top of Deptford Town Hall does not reveal its cargo. The four figures on the front of the Town Hall provide an answer.

The first figure, Sir Francis Drake, is credited as the first captain to circumnavigate the world. However, it is remembered as only a footnote in most histories that in 1568 John Hawkins, accompanied by his young nephew and protégé Francis Drake and bankrolled by Elizabeth I, was able to 'obtain' between 400-500 West Africans and sell them in the West Indies (Anim-Addo 1995). Such were the profits from this arrangement that it was soon repeated, with Deptford and its renowned shipyards producing many of the vessels that were used in this commerce.

The second figure is not so well known outside of naval circles. Robert Blake was an admiral who served under Oliver Cromwell throughout the English Civil War, and this may be why, post-restoration, his achievements were not so well-reported in popular history books. In a series of naval battles in 1653 he defeated the Dutch Admiral Van Tromp to secure England's monopoly over the Atlantic trade triangle between Europe, West Africa and the Americas. Blake was also the author of the Fighting Instructions, a textbook of naval tactics that were the blueprint for the English Navy's supremacy during the age of sail. Cromwell went on to impose the plantation system on Jamaica, after ensuring its utility in Ireland.

The third figure, Horatio Nelson, is England's most celebrated naval hero. $\mathrm{He}$ commanded the Victory at Trafalgar, seeing off Napoleon and the French navy and losing his life in the process. There was much civic pride in Deptford for its association with Nelson. What is less well known is his extreme opposition to the abolition of the slave trade. In reference to William Wilberforce, chief amongst the abolitionists, he is alleged to have written from the Victory, that as long as he would speak and fight he would resist 'the damnable doctrines of Wilberforce and his hypocritical allies' (URL 2).

The Royal Naval Dockyards were closed in 1869, ending Deptford's 356-year reputation as 'the cradle of the navy' (Steele 1993:1). With the building of Deptford Town Hall the planners tried to capture the celebrity associated with Deptford's past glories. They were also keen to maintain a link with the present. The final figure on the front of the Town Hall is the admiral. There is nothing to pin on the composite, but we can see that at the apex of Pax Britannica in the early part of the twentieth century, the British navy was crucial in the subjugation of numerous peoples and ensured that the atlas was largely pink and blue; the pink showing the dominions of the British Empire and the blue the oceans that separated them and aided the exploitation of their resources.

\section{Deptford and the slave trade}

The accounts of the Atlantic slave trade, its establishment, its pursuance and its eventual demise are many and varied and beyond the scope of this work. However, the histories of these figures illustrate how the British Navy was key in the development of the Atlantic slave trade and the expansion of empire; therefore I was interested in how far Deptford was implicated in the slave trade. Beyond its initial 
development through Arab, Spanish and Portuguese traders it was English merchants and budding capitalists who developed slavery on an industrial scale. It would have been London merchants, ship builders and those who lived and worked in the Deptford area who would have benefited directly or indirectly from the trade in Africans.

As the weathervane on Deptford Town Hall reminds us, the area was a thoroughfare for ships and shipping. Ships were built and launched, refitted and repaired, unloaded and restocked on the Deptford waterfront. Many of those enriched by the African-Caribbean trade began and ended each trip at Deptford. They brought with them slaves, symbols of wealth. Deptford became a key area for these newly arrived individuals whose number would increase as the trade developed. Still other slaves may have found themselves in the vicinity via other routes. As sales or gifts, black people may also have come through a number of other ports before reaching Kentish London. (Anim-Addo 1995:26)

Although Deptford pales next to the major English transit ports of Bristol and Liverpool, it is culpable as an outfitter and destination. Liverpool has already publicly apologised for its role in the trade and Bristol is debating its past (Hill 2006).

There was a great deal of discussion regarding apology and reparation for the enslavement of Africans throughout the period of the 2007 UK abolition commemorations. In a high-profile debate that took place at the British Empire and Commonwealth Museum in Bristol, Toyin Agbetu - the director of Ligali, a panAfrican human rights organisation that 'actively campaign for cultural, economic, political and social justice on behalf of the African community' (URL 3)-made a poignant comment that illustrated what a real apology for the slave trade might consist of:

Are Africans ready to except an apology from Bristol? ... The answer to that is no. We don't want an apology. We don't believe that you are emotionally or culturally mature enough to understand what an apology means. (Agbetu 2006)

Agbetu went on to explain that there is a process required in order to make an apology meaningful and acceptable to the ancestors of enslaved Africans. This process involves recognising the role of the West in the slave trade, taking responsibility for its legacy-including racism and the current underdevelopment of Africa, and admitting being guilty of complicity in this legacy. When this understanding has been reached, then it might be possible to make a meaningful apology.

For Agbetu, regret, the acknowledgement of responsibility, is the crucial requirement of an apology. On 26 November 2006, Prime Minister Tony Blair expressed 'deep sorrow' on behalf of the nation for its part in the Atlantic slave trade. He asked that with the approaching bicentenary of slavery's abolition in the British Empire in 1807 we might 'condemn its existence utterly and praise those who fought for its abolition' (URL 4). However, Tony Blair's statement was not an apology, and was criticised by a number of organisations as having changed nothing in the relationship between Britain, Africa and the Caribbean; it could be interpreted to mean that the British state is not ready to address this ancestral guilt. It has thus far fallen to individuals and municipal areas (such as Liverpool) to offer their apologies.

I wondered what acknowledgement had been made in Deptford of its part in the slave trade and whose responsibility it might be. The Town Hall had been the centre of 
Deptford's civic focus before its amalgamation with Lewisham in 1969. It had become the focus again with the establishment of the Deptford City Challenge (DCC) urban regeneration programme in the 1990s. Since the Town Hall is now in Goldsmiths' hands, what responsibility does the College have to make an apology? I discussed the issue of an apology with Goldsmiths' warden and historian Geoffrey Crossick, who wrote his PhD thesis on nineteenth-century Deptford, Greenwich and Woolwich.

I think in my mind, there are different levels to this, different dimensions to this. One of them is, should Goldsmiths apologise for slavery? No, not Goldsmiths. As a College we weren't involved, our society was involved but that's different. Go to the other end of the range of responses. Does Goldsmiths have a responsibility to the black community around South East London? Of course it does, but it has that responsibility because it is a higher education institution located here, and those institutions which are high quality like Goldsmiths, which are international and global in their reach and in their interest and in their reputation, are nonetheless in a place, and no university in my mind can ever be so grand that it doesn't care about the place it is in, it has obligations to its place. (Geoffrey Crossick, interview, 11 August 2006)

The question of who is responsible to make an apology is also dependent on the terms of the College's ownership of the building. Michael Keith, head of the Centre for Urban and Community Research at Goldsmiths, was involved in evaluating the Deptford City Challenge urban regeneration programme prior to the College's acquisition of the Town Hall. He explained the considerations behind the deal.

So the compromise is that you do a long term lease to the College, but you maintain public access ... you've got these community bases within the Town Hall, but with the College having a tenancy of it. That was the way it was pitched to City Challenge. The College would have custodianship of the building, but it would still have public access. Now exactly what that has become is more interesting. (Michael Keith, interview, 16 August 2006)

In 2006, eight years after the Town Hall became part of Goldsmiths, the only remnant of the agreement that it would have a public facet is that PACE, the community-facing department, is based there. From the red light I encounter whenever I try my student swipe card at the front door of the Town Hall, it is apparent that there is no student access, let alone public access. The implication is that Goldsmiths are not honouring their own contractual obligations to the local community in relation to the Town Hall. How then might we be able to get the College to take responsibility on less prescriptive issues around the building?

\section{Goldsmiths College inside and out}

Since the 1980s higher education in the UK has been subject to a number of reforms and restructurings that have focused on three key elements: measuring 'teaching performance', judging 'research quality' and assessing 'institutional effectiveness' (Shore and Wright 1999:557). As a result, higher education institutions, including Goldsmiths, are currently engaged in debates about the accountability and responsibility of the institution in ensuring a quality 'student experience' that translates into value for money. As Shore and Wright explain, although the mechanisms of audit are aimed at improving quality and empowering academics, in reality they are often experienced as 'coercive and disabling' (Shore and Wright 
1999:557). Marilyn Strathern writes that the audit culture and the accountability practices that accompany it are becoming ubiquitous inside the academy: 'Audit ... constitutes a major shift of power: from the public to the professional, and from teachers, engineers and managers to overseers' (Strathern 2000:281). Shore and Wright suggest that in order to challenge the current neo-liberal orthodoxy of audit, anthropologists might 'develop our own ideas about audit processes that would be in keeping with our values' (1999:571, original emphasis). Neo-liberalism ensures that the academy is made accountable to the market, but how might these institutions be made accountable in other ways, perhaps in the anthropological nexus of the local and the global, or morally and ethically to notions of underdevelopment and human rights?

Several academics have, over the past decades, characterised the institution of the university as a mechanism of control and reproduction of bourgeois values (e.g. Cohn-Bendit 1968, Graeber 2007). Griff Foley (1999:64-70) argues that education in the West is competency-based in order to generate a flexible workforce for 'restructuring', or what he calls capitalist reorganisation. He states that educational institutions are not neutral in this process. They serve a capitalist system that has the flaws of unequal distribution of wealth, environmental destructiveness, and inherent fallibility.

Locally and internally Goldsmiths sits somewhere between two extreme characterisations. At one extreme the College is portrayed as calculating, malevolent towards the local community and focused only on its bottom line. At the other extreme (taken particularly by the College's marketing department) it is a unique educational facility with cross-fertilizing departments exploding in a mess of culture cool. For Les Back, Goldsmiths is characterised as a space where very important things happen, 'often beyond the apprehension of those people in senior positions within the institution' (Back 2003:15). To some degree all these characterisations may have some validity.

However, the idea of Goldsmiths as a malevolent force in New Cross persists. There is a perception that Goldsmiths is slowly creeping outwards to take over the local area. As local historian Neil Gordon-Orr points out,

Today it is the College itself that is an increasingly dominant force in the area-occupying not only its original site, but the Town Hall, the old St James Church, the former St James Primary School, the Laurie Grove public baths and other buildings that taken together constitute the former town centre of New Cross. (Gordon-Orr 2004:10)

In discussion with me, Gordon-Orr elaborated on the contradiction between Goldsmiths as a radical institution and as a going commercial concern.

I mean, if you look and see why there is so much music from this area, partly it's tied in with the fact that there have always been cheap places to live and squat. That's given people time and space to make music, and although in a way the cultural heritage industry uses that to market the area, at the same time it sets in place a process whereby those things are squeezed out for the future. And we can see that Goldsmiths College is in a way part of that process. If you look at the website they will tell you as part of their recruitment package that people like Linton Kwesi Johnson went here, and Malcolm McLaren, manager of the Sex Pistols, and John Cale from the Velvet Underground, and they use that very much as a marketing tool. But at the same time you could say that Goldsmiths is embroiled in that process 
where space for doing interesting things is gradually being squeezed out. By taking over empty and semi-derelict buildings, spaces for people to do those musical, social, political experiments are being curtailed. (Neil Gordon-Orr, interview, 8 March 2006)

There is a perception that Goldsmiths is in part responsible for the area's gentrification. The cheap housing and the lively mix of cultures in the area, which in turn make fascinating research subjects, are being replaced by a monoculture of predominately white, middle-class students (or wealthy overseas students). Understandably, the College's Warden, Geoffrey Crossick, sees the situation differently.

Goldsmiths has changed enormously, and so therefore my answer to your fellow students who say 'you can't change the College' is that it is inevitably changing all the time. It's changing under the momentum of outside social forces, obviously, but also under the influence of the kind of people who are students and staff, academic and non-academic, at Goldsmiths ... It is wrong to see Goldsmiths as this self-contained, inward-looking block which is resistant to the community around it, though I can understand why some might see it as that at times. (Geoffrey Crossick, interview, 11 August 2006)

Michael Keith has examined Goldsmiths' interaction with the local community. Through his involvement with Deptford City Challenge he has had long dealings with many players in local politics and community work.

\begin{abstract}
Mostly there was massive mistrust of the College locally about whether it was trying to grab all the money meant for local poor folk, and there was a belated attempt by the College to re-present itself. Again, I think there is a rounded picture to this, if you look at local employment and look at local spend and what it is that you define as the local economy. In terms of the engines of the local economy, a lot of it was and is tied to Goldsmiths College. If you've got 10,000 students coming to spend their money in the bars and restaurants and clubs, you've got a music scene, an arts scene that has a tie into what the College is doing. Now, as I say, there is a suite of documents produced by Manchester University and by the University of East London about how, and in truth, there are Faustian games being played about how much the universities are the drivers of the local economy, and how much broke universities are trying to claw lumps of money which some residents' organisations or community groups would see as theirs. That game was being played up and down the country in the 1990s. Goldsmiths played a kind of soft version of it. To be honest, they didn't get as much money as they could have done, but they were seen locally as pawing some of the money that other people might want. (Michael Keith, interview, 16 August 2006)
\end{abstract}

It is apparent that local people resent the College because of its seemingly ubiquitous presence in New Cross. I was interested to find out if outside involvement in the Town Hall campaign might mitigate some of these feelings.

\title{
Recent Deptford history in relation to race and racism
}

Returning to the idea of acknowledgement of past events, there are two major recent events that the College has either failed or been tardy in acknowledging. These events happened just metres away from the College and have had national repercussions in relation to race and racism. If we are to ask the College to acknowledge the past 
misdeeds of long forgotten naval heroes, we should also look at more recent events that Goldsmiths has remained quiet about.

In our discussion Neil Gordon-Orr revealed the history of racism and resistance linked to Deptford:

There was always quite a strong presence in this area from the far right, going back to the British Union of Fascists in the 1930s. There was an instance when Oswald Moseley's fascists tried to march down New Cross Road and were repelled by a mass demonstration. And then you had in the 1960s and 70s the National Front and the National Party, an offshoot of the National Front, who at one point were doing quite well in local elections within this area. In 1976 the National Front and the National Party got a combined quote of nearly half the vote, $44.5 \%$, in a Deptford Council byelection. Then you had this whole key turning point, $13^{\text {th }}$ August 1977, when the National Front marched through Lewisham. (Neil Gordon-Orr, interview, 8 March 2006)

On that day in August 1977, the National Front met in New Cross with the intention of marching to Lewisham, but were met at Clifton Rise (outside the New Cross Inn) by thousands of militant anti-fascists. The fight that ensued saw the British police break out riot shields for the first time on the British mainland.

Crucially, Goldsmiths has been and is the home to prominent academics and students involved in addressing racism, including Linton Kwesi Johnson, Paul Gilroy and Les Back. In our discussion, Les Back remembered the 1977 march and its effect on him.

So part of that obsession is to make sense of how a place like Deptford can be the stage for some quite extraordinary reckonings with and rejections of hate and racism, at the same time as also being the stage that is marked by those divisions, and reproduces those divisions. It's absolutely a place where this drama of reckoning, transgressing and imagining a future beyond racism is being lived on more or less a daily basis, at the same time as being a place where racism can be voiced, articulated and reproduced. It's that tension, if you like, that paradoxical link, that has always compelled me. (Les Back, interview, 3 March 2006)

Four years later Deptford again found itself in the middle of the debates around race and racism. On Sunday 18 January 1981, a fire broke out at 439 New Cross Road. At the time the house was packed with local black youth enjoying a birthday party. The alarm was raised, but 13 young people perished in the flames, with a further 30 being injured or disfigured. The event was a turning point in community relations between immigrant black families and British institutions. Despite the size of the tragedy the event went largely unreported in the papers, and there was silence from then Prime Minister Margaret Thatcher. There was a righteous sense of injustice in the black community when, two weeks later, a fire in a Dublin disco received her public condolences (Phillips and Phillips 1998:324).

The investigation added to the tension. Following a long campaign of firebombing, it was alleged that the National Front had started the fire and that this was a racist murder rather than an accident enquiry. Relations between the police and the black community were already strained, but the police's handling of the subsequent enquiry led to a complete breakdown of community relations. Smith and Gray (1985:428-434) were doing research with the police at the time. Their analysis of the events following the fire characterised the police as defensive and unable to comprehend the political 
ramifications of the incident. Les Back recalled the events of 1981 in our discussion, and hinted at the magnitude of the event for the local black community:

That was the year that I came to live in this part of the borough. When the Deptford Fire happened and that was just [pause] and in a way I think that there is no marker on the house where the fire took place and all those people died. Part of my gut feeling about that and talking to people at that time, everybody knew somebody who died, not knew them personally but knew their family. (Les Back, interview, 3 March 2006)

It is perhaps telling that Firth's (1991) centenary account of the College does not mention this event. Although it chronicles a series of other local events unrelated to the College, the Deptford Fire is glaringly absent. It tells us what the College administration's relationship would have been with the black community only 16 years ago. Since this time the College has begun to redress this. Les Back recognises the changes.

I mean shamefully the College did very little, I think, and at that time the College was very much a white island in a very cosmopolitan sea, it really was, in the early 1980 s, shamefully so. I think it's great that the new Warden has instigated these scholarships, but we should have done it a long time ago. (Les Back, interview, 3 March 2006)

The scholarship that Les Back alludes to is the Mayor's New Cross Award, a bursary worth $£ 20,000$ per year, divided between one male and one female student from schools and colleges in the Borough of Lewisham to study at Goldsmiths. The setting up of this award, funded by Lewisham Borough Council, was one of the first engagements for Geoffrey Crossick when he came into post as Warden.

I genuinely don't know whether it is the case for younger people, but certainly there are generations of people in the local community for whom the New Cross Fire is still a major part of community memory, and I think that it is important for Goldsmiths to signal that, and to signal our recognition of its importance which, as Les said, didn't happen at the time in anything more than the most tokenistic of ways. (Geoffrey Crossick, interview, 11 August 2006)

The College's belated response shows that there is space for a campaign based around the Town Hall. I felt then that rather than the need for an apology from Goldsmiths for Deptford's part in slavery, what was really needed was a public acknowledgement of its connection. If nothing else, Goldsmiths' administration can see the utility of redressing wrongs and attempting to put them right.

\section{The dangers of doing nothing}

While there is space for a campaign at Goldsmiths, what would happen if we did nothing? Addressing the social responsibility of anthropologists during the Vietnam War, Berreman explained that 'our silence permits others in the society less reticent, perhaps less scrupulous, almost certainly less informed, to make their own use of the material presented' (1968:392). Could this happen with Deptford Town Hall?

David Goldberg (1990:xiv) has identified a historical shift in racist forms. He contends that whereas in the past racism was used to pursue colonial expansion, present forms find their expression in nationalism. Deptford Town Hall sits in the middle of this shift. As the generic admiral on the building testifies, Deptford Town 
Hall espouses the values of Britain's imperial past. It also has the potential for becoming part of the discourse of resurgent nationalism, based on what Rosaldo (1993) has identified as 'imperialist nostalgia'.

Gilroy (2002:xxiii) suspects that racism persists because we have not come to terms with the tragedy of Empire gained and, more importantly, Empire lost. Without addressing our own imperialist nostalgia, there is little chance that we will be able to practically address racism. The discourse concerning Deptford Town Hall statues is bound up with imperialist nostalgia for 'Great Britain'. If we do nothing, we are leaving it open for other organisations to do something with potentially negative consequences.

\section{Knocking down the Town Hall?}

Having decided that something should be done, the question was what should we do? When we look at the figures atop the building we see in them the ideals and the power relations of a previous imperial age. Weisman (1994) reminds us that,

we must ... recognise that the spatial form of public architecture is but a reflection of a comprehensive system of institutionalised racism, sexism, and classism that must first be understood and then transformed in order to change realistically the 'institutional' buildings it produces. (Weisman 1994:63-64)

The transformation that Weisman hints at could take many forms, with the most obvious being to pull down the building or replace the statues with more appropriate icons.

The Mark Lewis and Laura Mulvey film Disgraced Monuments dealt with the popular reaction to the monuments of the Soviet Empire following its collapse in the early 1990s. After the Tsar's overthrow in 1917, Lenin decreed that the Tsarist monuments throughout Russia should be pulled down and in their place monuments should be raised to the republic. Lenin created an approved list which subsequent to his death featured only his name. The Soviet party went on to replace the statues, and changed street and city names in order to purge Russia of its previous history. A huge industry had built up over many years of artists and factories producing busts of Lenin, Marx and other worthies of the Soviet era. One of the respondents in the documentary makes the point that although these objects are removed, the present culture is still linked to the previous one. There is no difference in culture between these periods, as the rulers continue to raise statues and monuments to their achievements. The Russians came full circle after the end of the Soviet era when they pulled down old idols and raised new ones in their place.

One artist in the film points out, 'It's an act of chauvinism, fascism, philistinism to remove monuments that don't suit the current political regime'. As the directors Lewis and Mulvey emphasise, we are doomed to repeat ourselves if we tear down one set of monuments and replace them with another.

\section{Building the Town Hall}

Returning to his own historical studies, the Warden Geoffrey Crossick pointed out to me that Deptford was in decline by the time of the Town Hall's completion in 1905. He also asked a pertinent question: 
In 1869 the Dockyards closure ... might have hit the local workers, but it was not going to hit local employers particularly. The point is that by the 1860 s70 s, what I mean by 'socially in decline' is that the middle class was moving out of Deptford. It was moving to Lee, to Lewisham. So this was an area that was becoming by then a working-class area, by the time that the Town Hall was built-so who was deciding on this grand Town Hall? (Geoffrey Crossick, interview, 11 August 2006)

Deptford Town Hall would have been designed to evoke certain memories for the inhabitants of Deptford. As elders in their community, the bearded men who commissioned the building would have been of an age to remember the dockyards and Deptford in the age of sail. The monument that they commissioned was a reminder that these British celebrities had once been associated with their town, and it may have given the residents a morale boost at a time of social and economic decline.

Today there is a new set of memories attached to the Town Hall and the surrounding area. Within Goldsmiths College we have the resources to make a very different analysis of the building's meaning, especially in relation to race and racism. In his introduction to the Texture of Memory, James Young explains that,

New generations visit memorials under new circumstances and invest them with new meanings. The result is an evolution in the memorial's significance, generated in the new times and company in which it finds itself. (Young 1993:3)

An illustration of this process in action is Stonehenge, the iconic Neolithic stone circle in Wiltshire. The stones are the centre of a dispute over its meaning and use between 'experts' in the heritage industry, who are trying to restrict access to the site, and neopagans, who want to use the stones as a place of worship. Letcher et al. (2003:2) point out that Stonehenge is a palimpsest, with a long history of alteration, change, development, abandonment and reuse. The term 'palimpsest' is usually used in reference to a manuscript that has been written over and reused many times, but which still retains some trace of the original.

Deptford Town Hall has the potential to become a palimpsest of sorts, but the job of overwriting the text has yet to be done. The work we need to do, then, is to overwrite the building with a new set of memories and meanings. The Town Hall retains its original jingoistic overtones, but these serve only for us to reject the imperialist nostalgia and to create a better-informed relationship with the building. The work of generating new meanings is already being done. One local resident, who wished to remain anonymous, supplied me with an alternative narrative for the figures on the front of Deptford Town Hall that plays on the legacy of sadness and regret. The resident said that, as penance for their past misdeeds, the souls of these noble seamen are trapped for eternity inside the statues. They are forced to watch the multiculturalisation of New Cross and rue their past actions.

\section{Action}

In overwriting the building we need to decide what forms the process will take. Precedent has been set in various contemporary contexts. Young has made extensive studies of Holocaust monuments and memorials. His work asks us to consider the nature of memory and how we consider memorials and monuments to do the work of memory: 
To the extent that we encourage monuments to do our memory-work for us, we become that much more forgetful. In effect, the initial impulse to memorialize events like the Holocaust may actually spring from an opposite and equal desire to forget them. (Young 1992:273)

The memorials that he deals with are those remembering (or forgetting) the Holocaust. Young explains that due to the critical reappraisal of the function of monuments there have been a number of attempts to create counter-monuments. These objects sit near or over the previous monument and act to subvert or comment on the original.

In addressing how societies forget, Forty and Küchler refer to Connerton's (1989) argument that in societies 'material objects have less significance in perpetuating memory than embodied acts, rituals and normative social behaviour' (Forty and Küchler 1999:2) If this is the case, then addressing the physical form of Deptford Town Hall would seem to be an ineffective way to deal with the legacy of slavery. For Les Back, Deptford is both the place where the fight against racism is being fought, simultaneously with it being the site of racism's reproduction. The recent history of Deptford testifies that the rituals of the struggle against racism may have become normative behaviour for Deptford, New Cross and Goldsmiths. Like the pagans at Stonehenge who re-create rituals of times past, the residents of Deptford struggle against racism repeating the rituals of resistance. The local elections in May 2002 saw Goldsmiths students re-enacting this ritual:

Ian Page ... was also nearly arrested outside the count when he confronted the BNP [British National Party] candidate in Downham ward. Over 300 anti-Nazi protesters mainly from Goldsmiths College formed a lobby to stop the BNP entering the count. (URL 5)

\section{Castles in Ghana}

How would the re-presentation of the history of slavery be made in relation to Deptford Town Hall? In representing history we will be reintroducing characters who were initially written out of the plot. 'The historic invisibility of many of the ... subjects owes much to the repression originally visited upon them' (Linebaugh and Rediker 2000:6). We have to be careful in our casting of this new drama. Although these people have been repressed, we should not view them as victims. Gilroy rejects victimhood and proposes that we 'install instead an alternative conception which sees us as an active force working in many different ways for our freedom from racial subordination' (Gilroy 1992:60).

The complexity of this debate is illustrated at the Cape Coast and Elmina Castles in Ghana. Various European interests established these sites as secure bases from which to operate in the Atlantic slave trade. They have subsequently become places of pilgrimage or 'slavery tourism' for thousands of African Americans. There is a struggle over their representation between authorities in Ghana, who are trying to maintain tourist incomes, and African American lobby groups, who want to prevent 'Disneyfication' of the sites.

Osei-Tutu (2004) explains that these castles have had a history that did not remain in stasis following the abolition of slavery. They were put to other purposes as prisons, schools and administrative centres. They are currently used to attract diasporic tourists, and Ghanaian authorities have set about restoring the castles for this purpose. 
African Americans are in dispute with the Ghanaian authorities over the perceived beautification and whitewashing of the monuments, which they feel takes away their opportunity to have an authentic sense of their ancestors' experience.

This conflict has resulted in African Americans attempting to educate Ghanaians to ensure that their understanding of the slave trade is the predominant one. Osei-Tutu suggests that 'rather than trying to rewrite history, both Ghanaians and African Americans must appreciate that they bring different perspectives to the slave trade because of their different historical backgrounds' (Osei-Tutu 2004:201). He calls for compromise to ensure that the monuments are handled 'with sensitivity and reverence' (Osei-Tutu 2004:202).

\section{Conclusion}

In order for the Town Hall to stand as a monument that recognises the history of slavery, the work of memorialising slavery and racism through ritual has to be done. Our next task is to decide what forms these rituals might take. As Goldsmiths is an academic institution, I considered employing the academic rituals of conferences and seminars.

In June 2007 a conference was arranged in Deptford Town Hall which featured a number of speakers on a range of subjects related to slavery, resistance, apology and reparation. Members of the Christian-orientated Lifeline Expedition (URL 6), who wander around the world in chains apologising for slavery, were invited to come into the Town Hall and were welcomed by the Warden on the steps of the building. They came into the building and made a public apology and took off their chains. In order to consciously redress the official commemoration's focus on Wilberforce and abolition, Jean Besson gave an account of the ancestors of the Jamaican Maroons, who had actively resisted slavery. African commentators such as William 'Lez' Henry, Toyin Agbetu and Esther Stanford questioned the validity of the apology, and explained what reparations were necessary. This is perhaps an important beginning in having Goldsmiths acknowledge its responsibility as owner of this building and custodian of these controversial figures, and a beginning that suggests how it might support future exploration of this issue.

By raising the profile of Deptford Town Hall as a controversial monument we will provoke wider public reaction. This reaction might be positive or negative, but as Young points out, "it is ... the dialectic between a monument and its public, the tension between it and its surroundings, that sustains memory and occludes complacency' (Young 1993:40).

\section{References}

Anim-Addo, J. 1995. Longest Journey: A History of Black Lewisham. London: Deptford Forum Publishing.

Agbetu, T. 2006. The British Empire and Commonwealth Museum Bristol apology debate. Transcript of speech, Bristol, 10 May 2006.

Back, L. 2003. Written in Stone, Black British Writing and Goldsmiths College. Unpublished paper. 
Berreman, G.D. 1968. Is anthropology alive? Social responsibility in social anthropology. Current Anthropology 9(5), 391-396.

Borough of Deptford. 1905. Souvenir of the Opening of the Town Hall. London: Gaylard.

Cohn-Bendit, D. 1968. Obsolete Communism: The Left-Wing Alternative. London: Penguin.

Connerton P. 1989. How Societies Remember Cambridge: Cambridge University Press.

English Heritage. 2006. Deptford Town Hall. Leaflet available from Deptford Town Hall reception.

Firth, A.E. 1991. Goldsmiths College: A Centenary Account. London: Athlone.

Foley, G. 1999. Learning in Social Action: A Contribution to Understanding Informal Education. London: NIACE.

Forty, A. and S. Küchler (eds). 1999. The Art of Forgetting. Oxford: Berg.

Freire, P. 1972. Pedagogy of the Oppressed. Harmondsworth: Penguin Education.

Gilroy, P. 1992. The end of anti-racism. In 'Race', Culture and Difference (eds) J. Donald and A. Rattansi, 49-61. London: Sage, and the Open University.

-------. 2002. 'There Ain't No Black in the Union Jack': The Cultural Politics of Race and Nation. London: Routledge.

Goldberg, D.T. (ed.). 1990. Anatomy of Racism. London: University of Minnesota Press.

Gordon-Orr, N. 2004. Deptford Fun City: A Ramble Through the History and Music of New Cross and Deptford. South London: Past Tense.

Graeber, D. 2007. Army of altruists. Harper's Magazine 2007 (January), 31-38.

Hill, A. 2006. City agonises over slavery apology. The Observer 7 May 2006.

Kemmis, S. and M. Wilkinson. 1998. Participatory action research and the study of practice. In Action Research in Practice (eds) B. Atweh, S. Kemmis and P. Weeks, 21-36. London: Routledge.

Kirsch, S. 2002. Anthropology and advocacy: A case study of the campaign against the Ok Tedi mine. Critique of Anthropology 22(2), 175-200.

Letcher, A., J. Blain and R. J. Wallis. 2003. Re-viewing the past: Discourse and power in images of prehistory. Paper presented at the conference Still Visions, Changing Lives, Sheffield Hallam University, July (http://www.sacredsites.org.uk/papers/visions.html).

Linebaugh, P. and M. Rediker. 2000. The Many-Headed Hydra: The Hidden History of the Revolutionary Atlantic. London: Verso.

Osei-Tutu, B. 2004. African American reactions to the restoration of Ghana's 'slave castles'. Public Archaeology 3, 195-204.

Phillips, M. and T. Phillips. 1998. Windrush: The Irresistible Rise of Multi-Racial Britain. London: Harper Collins.

Robson, C. 2002. Real World Research. Oxford: Blackwell. 
Rosaldo, R. 1993. Culture and Truth: Remaking of Social Analysis. London: Routledge.

Scheper-Hughes, N. 1995. The primacy of the ethical: Propositions for a militant anthropology. Current Anthropology 36(3), 409-440.

Scott, J.W. 1989. History in crisis: the others' side of the story. American Historical Review 94(3), 680-692.

Shore, C. and S. Wright. 1999. Audit culture and anthropology: Neo-liberalism in British higher education. Journal of the Royal Anthropological Institute (N.S.) 5, 557-575.

Smith, D.J. and J. Gray. 1985. Police and People in London: The PSI Report. Aldershot: Gower.

Steele, J. 1993. Turning the Tide: The History of Everyday Deptford. London: Deptford Forum Publishing.

Strathern, M. 2000. Accountability... and ethnography. In Audit Cultures: Anthropological Studies in Accountability, Ethics and the Academy (ed.) M. Strathern, 279-304. London: Routledge.

Thompson, N. 2000. Theory and Practice in Human Services. Buckingham: Open University Press.

Weisman, L.K. 1994. Discrimination by Design: A Feminist Critique of the ManMade Environment. Chicago: Illini Books.

Young, J.E. 1992. The counter-monument: Memory against itself in Germany today. Critical Inquiry 18(2), 267-296.

Young, J.E. 1993. The Texture of Memory: Holocaust Memorials and Meaning. New Haven: Yale University Press.

\section{Films}

Disgraced Monuments. 1996. M. Lewis and L. Mulvey.

\section{Websources}

URL 1. Leading social theorist, Professor Paul Gilroy, receives Honorary Degree at Goldsmiths. Goldsmiths press release, 7 September 2005.

http://www.goldsmiths.ac.uk/press-releases/pressrelease.php?releaseID=403

URL 2. William Wilberforce Biography. The Wilberforce School. http://www.wilberforceschool.org/38436.ihtml

URL 3. Ligali website. http://www.ligali.org/

URL 4. Blair 'regret' over slavery not enough, say campaigners. The Times Online, 27 November 2006. http://www.timesonline.co.uk/article/0,22474141,00.html

URL 5. Increased votes for socialism in Lewisham. Socialist party website. http://www.socialistparty.org.uk/ElectionCampaignLewisham.htm 
URL 6. 'My ancestor traded in human misery'. BBC News, 23 June 2006. http://news.bbc.co.uk/1/hi/uk/5105328.stm

\section{About the author}

Paul Hendrich studied Applied Anthropology, Youth and Community Work at Goldsmiths whilst working as a youth and community worker in South London. He is currently completing his MRes in Social Anthropology at the same college and preparing to sail away to Arizona to begin his fieldwork towards his doctorate. His interests include local history, racism and resistance, vigilantes, activism, and migration. He has recently contributed to the Lewisham'77 project commemorating the Battle of Lewisham which took place on Goldsmiths' doorstep in 1977 (http://lewisham77.blogspot.com).

Editor's note: After having finalised his article for publication, and having written the above blurb about himself, Paul Hendrich suddenly and tragically died on January 16, 2008. Alpa Shah has written further on his engaged work and interests in the editorial to this issue. Our thoughts go to his wife and his daughter, his family and friends. 